\title{
Overview of Motor Nerve Damage in People with Diabetes Mellitus
}

\author{
Ana Nistiandani ${ }^{1 *}$, Rondhianto Rondhianto², Muhammad Fakhrur Rozsy ${ }^{3}$ \\ 1,2Departement of Medical-Surgical Nursing, Faculty of Nursing, Universitas Jember, Indonesia; \\ nistiandani@unej.ac.id (Corresponding Author) \\ ${ }^{3}$ Nurse Practitioner, dr. Soebandi General Hospital, Jember, Indonesia
}

\begin{tabular}{|c|c|}
\hline Article Info: & ABSTRACT \\
\hline $\begin{array}{l}\text { Submitted: } \\
\text { 30-10-2021 } \\
\text { Revised: } \\
\text { 28-12-2021 } \\
\text { Accepted: } \\
\text { 29-12-2021 }\end{array}$ & $\begin{array}{l}\text { Damage to motor nerves in people with diabetes increases the risk of a foot injury. So } \\
\text { far, the examination of motor nerve damage in people with diabetes in agricultural } \\
\text { areas such as the Jember Regency is still rarely touched by primary health services. } \\
\text { The purpose of this study was to identify motor nerve damage in people with diabetes } \\
\text { in the agriculture area of the Jember Regency. This type of research is exploratory, } \\
\text { descriptive, } 102 \text { respondents obtained by purposive sampling technique. Data } \\
\text { collection uses instrument modification from MNSI (Michigan Neuropathy Screening } \\
\text { Instrument) and MDNS (Michigan Diabetic Neuropathy Score). The analysis used in } \\
\text { univariate and displayed in the frequency distribution. The results showed that the } \\
\text { majority of respondents who suffer from DM are experienced in the middle adulthood } \\
\text { category ( } 71.6 \%) \text {, with a length of suffering more than five years (95.1\%), and have a }\end{array}$ \\
\hline $\begin{array}{l}\text { DOI: } \\
\text { https://doi.org/10.53713/nhs.v1i3.83 }\end{array}$ & $\begin{array}{l}\text { history of comorbidities }(68.6 \%) \text {. The most common form of motor deformity damage } \\
\text { was hallux valgus on the right and left legs }(38.2 \% ; 26.4 \%) \text {. Forms of motor damage in } \\
\text { the form of muscle strength, severe damage to the abduction of the right and left legs } \\
(7.8 \%) \text {, and were found right or left toe extensions (1.9\%; } 2.9 \%) \text {. Motor damage in the } \\
\text { form of no physiological reflexes was found in the right and left Quadriceps femoral } \\
(2 \% ; 1 \%) \text {, and right or left leg Achilles }(1 \%) \text {. The result of total motor damage } \\
\text { assessment is that people with diabetes have decreased muscle strength in the right } \\
\text { and left extremities ( } 74.5 \% ; 72.5 \%) \text {. This research shows that the majority of people } \\
\text { with diabetes in the agriculture area of the Jember Regency suffer motor nerve } \\
\text { damage. Therefore, there is a need for preventive measures to prevent the worsening } \\
\text { condition of people with diabetes. }\end{array}$ \\
\hline
\end{tabular}

This work is licensed

under CC BY-SA License.

Keywords: agriculture; diabetes mellitus; motor nerve damage

\section{INTRODUCTION}

Jember Regency is an agricultural region that has a high number of Diabetes Mellitus (DM) visits in 2018, 36,834 (PEMKAB Jember, 2012; Dinas Kesehatan Kab. Jember, 2019). The relatively high prevalence of DM in Jember was allegedly the possibility of exposure to the use of pesticides in agriculture. Reinforced by previous research, which states that exposure to pesticides can affect beta cells in producing the hormone insulin, so that blood sugar levels become high and DM will occur(Saputri, Setiani, YD, \& Budiyono, 2018).

DM causes various complications, one of which is peripheral neuropathy (World Health Organization, 2016). Based on the results of Riset Kesehatan Dasar (2013) showed that the most complications of DM are neuropathy, and experienced by around $54 \%$ of clients treated at Cipto Mang unkusumo Hospital. Peripheral neuropathy that occurs can cause permanent disability such as amputation, which is caused by injuries with improper care (Al-rubeaan et al., 2015). Also, people with diabetes who have a history of DFU and previous amputations will aggravate the level of peripheral neuropathy of people with diabetes (Al-rubeaan et al, 2015).

Alik \& Roup Research (2010) explains that motor nerve damage is a part of peripheral neuropathy, and currently, it is rarely examined by primary health care (Bansal et al., 2014). Damage to motor nerves causes muscle atrophy, leg deformity, changes in foot biomechanics, and pressure distribution will be disrupted so that it can cause diabetic foot injuries (Kartika, 2017). So far many studies have discussed diabetic peripheral neuropathy in general, but it is very rarely associated with motor nerve damage and especially in agricultural areas. 


\section{METHOD}

This type of research is exploratory descriptive. Descriptive research only analyzes and presents data system this explorative, descriptive study aims to describe the phenomenon of motor nerve damage in people with diabetes, not to test a hypothesis. The population in this study were all DM clients in the agricultural district of Jember, which included Jelbuk and Sukorambi Districts. The total population is 1373 people with diabetes. The sample in this study uses Total Population Sampling, which is a type of purposive sampling technique in which sample selection based on specific characteristics. Inclusion criteria set by researchers include people with diabetes> 18 years old, people with diabetes who do not have active DFU, people with diabetes who did not experience amputation in both legs.

From the results of sample calculation using the Slovin formula, the minimum number of samples is 93 . However, in this study, 102 people who participated in it, so all subjects who met the criteria for the sample. Data collection uses instrument modification from MNSI (Michigan Neuropathy Screening Instrument) and MDNS (Michigan Diabetic Neuropathy Score). MNSI items are used in inspection for deformity, while MDNS using for forms of physiological reflex damage and muscle strength.

\section{RESULT}

\section{Demographic Charateristics of people with diabetes}

Table 1. Demographic Characteristics

\begin{tabular}{|c|c|c|}
\hline Respondent Category & Frequency & Percentage (\%) \\
\hline \multicolumn{3}{|l|}{ 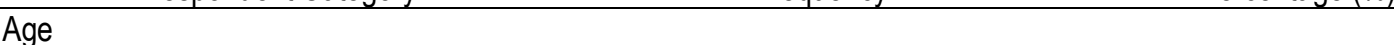 } \\
\hline Early adulthood & 12 & 11.8 \\
\hline Middle adult & 73 & 71.6 \\
\hline Late adulthood & 17 & 16.7 \\
\hline \multicolumn{3}{|l|}{ Sex } \\
\hline Male & 47 & 46.1 \\
\hline Female & 55 & 53.9 \\
\hline \multicolumn{3}{|l|}{ Duration of DM } \\
\hline$<1$ & 5 & 4.9 \\
\hline $1-5$ & 60 & 58.8 \\
\hline$>5$ & 37 & 36.3 \\
\hline \multicolumn{3}{|l|}{ Blood sugar levels } \\
\hline$<90 \mathrm{mg} / \mathrm{dL}$ & 5 & 4.9 \\
\hline $90-199 \mathrm{mg} / \mathrm{dL}$ & 59 & 57.8 \\
\hline$\geq 200 \mathrm{mg} / \mathrm{dL}$ & 38 & 37.3 \\
\hline \multicolumn{3}{|l|}{ History of Smoking } \\
\hline Yes & 69 & 67.6 \\
\hline No & 33 & 32.4 \\
\hline \multicolumn{3}{|l|}{ History of comorbidities/Complication } \\
\hline Yes & 70 & 68.6 \\
\hline No & 32 & 31.4 \\
\hline \multicolumn{3}{|l|}{ Types of comorbidities/Complication } \\
\hline Hipertension & 61 & 59.8 \\
\hline Stroke & 5 & 4.9 \\
\hline Coronary heart disease & 0 & 0 \\
\hline CKD & 2 & 2 \\
\hline Etc.. & 2 & 2 \\
\hline \multicolumn{3}{|l|}{ History of DFU } \\
\hline Yes & 10 & 9.8 \\
\hline No & 92 & 90.2 \\
\hline Total & 102 & 100 \\
\hline
\end{tabular}

Table 1 shows that the majority of people with diabetes are in the middle adulthood category $(71.6 \%)$, with more than five years $(95.1 \%)$, and with a history of comorbidities $(68.6 \%)$. 


\section{Description of Motor Nerve Damage}

\section{Deformity}

Table 2. Frequency distribution of motor damage in the form of deformity

\begin{tabular}{|c|c|c|}
\hline Checking Type & Frequency & Percentage (\%) \\
\hline \multicolumn{3}{|l|}{ Flat feet } \\
\hline Right foot deformity & 15 & 14.7 \\
\hline Left foot deformity & 15 & 14.7 \\
\hline Both No Deformity & 72 & 70.6 \\
\hline \multicolumn{3}{|l|}{ Hammer toes } \\
\hline Right foot deformity & 20 & 19.6 \\
\hline Left foot deformity & 19 & 18.6 \\
\hline Both No Deformity & 63 & 61.8 \\
\hline \multicolumn{3}{|l|}{ Claw toes } \\
\hline Right foot deformity & 8 & 7.8 \\
\hline Left foot deformity & 7 & 6.9 \\
\hline Both No Deformity & 87 & 85.3 \\
\hline \multicolumn{3}{|l|}{ Mallet toes } \\
\hline Right foot deformity & 7 & 6.9 \\
\hline Left foot deformity & 4 & 3.9 \\
\hline Both No Deformity & 91 & 89.2 \\
\hline \multicolumn{3}{|l|}{ Overlapping toes } \\
\hline Right foot deformity & 1 & 0.1 \\
\hline Left foot deformity & 1 & 0.1 \\
\hline Both No Deformity & 100 & 98.8 \\
\hline \multicolumn{3}{|l|}{ Hallux valgus } \\
\hline Right foot deformity & 39 & 38.2 \\
\hline Left foot deformity & 27 & 26.4 \\
\hline Both No Deformity & 36 & 35.3 \\
\hline \multicolumn{3}{|l|}{ Prominent metatarsal heads } \\
\hline Right foot deformity & 3 & 2.9 \\
\hline Left foot deformity & 2 & 2 \\
\hline Both No Deformity & 97 & 95.1 \\
\hline \multicolumn{3}{|l|}{ Charchot foot } \\
\hline Right foot deformity & 1 & 0.1 \\
\hline Left foot deformity & 1 & 0.1 \\
\hline Both No Deformity & 100 & 98.8 \\
\hline Total & 102 & 100 \\
\hline
\end{tabular}

Table 2, show that the most common deformity found on the right foot is hallux valgus, as many as 39 respondents $(38.2 \%)$, while the deformity on the left foot was mostly found in the hallux valgus by 27 respondents (26.4\%). 


\section{Muscle Strength}

Table 3. Distribution of the frequency of motor damage in the form of muscle strength

\begin{tabular}{lcc}
\hline \multicolumn{1}{c}{ Scoring } & Frequency & Percentage (\%) \\
\hline Abduction of the right toe & 47 & \\
$\quad$ Normal & 47 & 46.1 \\
Moderate & 8 & 46.1 \\
$\quad$ Severe & 47 & 7.8 \\
Abduction of the left toe & 47 & 46.1 \\
$\quad$ Normal & 8 & 46.1 \\
$\quad$ Moderate & 48 & 7.8 \\
$\quad$ Severe & 52 & \\
Extension the right toe & 2 & 47.1 \\
$\quad$ Normal & & 51 \\
Moderate & 51 & 1.9 \\
$\quad$ Severe & 48 & 50 \\
Extension the left toe & 3 & 47.1 \\
$\quad$ Normal & & 2.9 \\
Moderate & 58 & 56.9 \\
$\quad$ Severe & 44 & 43.1 \\
Dorsoflexion right ankle & 0 & 0 \\
$\quad$ Normal & & \\
Moderate & 60 & 58.8 \\
$\quad$ Severe & 42 & 41.2 \\
Dorsoflexion left ankle & 0 & 100 \\
$\quad$ Normal & 102 & \\
Moderate & & \\
Severe & Total &
\end{tabular}

Table 3 shows that the results of muscle strength tests that had the most normal values on the right and left legs were ankle dorsiflexion as many as 58 people $(56.9 \%)$ and 60 people $(58.8 \%)$. While those with the most moderate value on the right and left foot were toe extensions, 52 respondents $(51 \%)$, and 48 respondents $(47.1 \%)$. Forms of severe damage were found on the right and left abduction (7.8\%), and right and left toe extensions (1.9\%; $2.9 \%)$.

\section{Physiological Reflexes}

Table 4. Distribution of the frequency of motor damage in the form of physiological reflexes

\begin{tabular}{lcc}
\hline \multicolumn{1}{c}{ Scoring } & Frequency & Percentage (\%) \\
\hline Right biceps brachii & & \\
$\quad$ Reflexes normal & 60 & 58.8 \\
Less of reflex & 42 & 41.2 \\
$\quad$ No Reflex & 0 & 0 \\
Left biceps brachii & & \\
$\quad$ Reflexes normal & 60 & 58.8 \\
Less of reflex & 42 & 41.2 \\
$\quad$ No Reflex & 0 & 0 \\
Right triceps brachii & & \\
Reflexes normal & 59 & 57.8 \\
Less of reflex & 43 & 42.2 \\
$\quad$ No Reflex & 0 & 0 \\
Left triceps brachii & & \\
Reflexes normal & 61 & 59.8 \\
Less of reflex & 41 & 40.2 \\
No Reflex & 0 & 0 \\
\hline
\end{tabular}


Table 4. Distribution of the frequency of motor damage in the form of physiological reflexes (cont.)

\begin{tabular}{lcc}
\hline \multicolumn{1}{c}{ Scoring } & Frequency & Percentage (\%) \\
\hline Right quadriceps femoral & & \\
$\quad$ Reflexes normal & 48 & 47.1 \\
Less of reflex & 52 & 51 \\
$\quad$ No Reflex & 2 & 2 \\
Left quadriceps femoral & 49 & 48 \\
$\quad$ Reflexes normal & 52 & 51 \\
$\quad$ Less of reflex & 1 & 1 \\
$\quad$ No Reflex & 48 & \\
Right Achilles & 53 & 47.1 \\
$\quad$ Reflexes normal & 1 & 52 \\
Less of reflex & & 1 \\
$\quad$ No Reflex & 49 & 48 \\
Left Achilles & 52 & 51 \\
$\quad$ Reflexes normal & 1 & 1 \\
Less of reflex & 102 & 100 \\
$\quad$ No Reflex & & \\
\hline$\quad$ Total & & \\
\hline
\end{tabular}

Table 4 shows the examination of physiological reflexes, where the majority of people with diabetes still have reflexes on the right and left biceps brachii (58.8\%; 8.8\%), right and left Triceal brachii (57.8\%; 59.8\%). Physiological reflexes that are dominated by reflexes are lacking in the right and left quadriceps femoral muscles (51\%; $51 \%)$, right and left Achilles $(52 \% ; 51 \%)$. Motor damage in the form of no physiological reflexes was found in the right and left Quadriceps femoral (2\%; $1 \%)$, and right or left leg Achilles (1\%).

\section{Motor Damage Assessment Results}

Table 5 Frequency distribution of motor damage assesement results $(n=102)$

\begin{tabular}{lcc}
\hline \multicolumn{1}{c}{ Scoring } & Frequency & Percentage (\%) \\
\hline Right Leg & 26 & 25.5 \\
Normal & 76 & 74.5 \\
Decreased of muscle strength & 0 & 0 \\
No muscle strength & & \\
Left Leg & 28 & 27.5 \\
Normal & 74 & 72.5 \\
Decreased of muscle strength & 0 & 0 \\
No muscle strength & 102 & 100 \\
\hline Total & &
\end{tabular}

Table 5. shows that a decrease dominated the results of the motor damage assessment in muscle strength on the right side by 76 people with diabetes $(75.4 \%)$ and the left leg with 74 people with diabetes $(72.5 \%)$.

\section{DISCUSSION}

The results of this study indicate that increasing age is a risk factor for DM; in Table 1, which shows the middle and late adulthood of 90 people (88.3\%). In theory, as the age increases, the body will decrease its function as well as the ability of $\beta$ cells to produce insulin to metabolize glucose (Betteng, Pangemanan, \& Mayulu, 2014; Iroth, Kandou, \& Malonda, 2017). Likewise, the results of RISKESDAS in 2014 showed that the proportion of people with diabetes increased with age, and the category of adult age was in the highest proportion (Kementerian Kesehatan RI, 2014).

The results showed that the majority of people with diabetes had had diabetes for more than five years. This result is in line with Nistiandani, Juniarto, \& Dyan research (2018) which shows that the majority of people with diabetes who have examined themselves in poly have suffered more than five years. This condition is a logical occurrence, because DM is a chronic disease, and if the sufferer can control blood sugar levels properly, his quality of life will improve. 
The majority of people with diabetes in this study had 70 people (68.6\%). In line with the research ofNistiandani et al. (2018), the majority of people with diabetes have comorbidities. Chronic hyperglycemia can cause ischemia in various organs and cause other diseases such as hypertension and diabetic ulcers (Arsono, 2005).

Forms of examination of motor damage to the foot include checking deformity, checking muscle strength, and checking reflexes. This study shows that the deformity most commonly found in both legs is hallux valgus. The research here is different from what was found by Rosyida (2016) found that the deformity that often appears in people with diabetes is hammertoes.

Other studies also show different results than the most commonly found deformity is claw toes(Bus, Maas, Michels, \& Levi, 2009).The researcher's assumptions are based on previous research and theory, differences in the results of research in the findings of the form of foot deformity can occur. Due to damage to nerve fibers, intrinsic muscles due to hyperglycemia do not look at the anatomical structure of the foot.

A deformity that occurs results in weakness and limitations in the foot due to the accumulation of collagen under the dermis, resulting in stiffness and deformation of the toe (Bus et al., 2009). This condition can be experienced by people with diabetes who rarely carry out activities such as sports and the habit of wearing narrow footwear that makes it difficult to move their feet (Syafi'i, 2018).

In addition to deformity, checking muscle strength is an assessment item of motor nerve damage. This study showed that severe damage founding in the right and left abduction (7.8\%), and right and left toe extensions (1.9\%; $2.9 \%$ ). This is in line with the study of Rosyida (2016) who found the most severe disruption was foot abduction. This disorder occurs because there is stiffness in the distal extremities due to the peroneus communis nerve (Schie, Vermigli, Carrington, \& Boulton, 2016). This can occur because, in theory, N. peroneus communis is prone to injury, which can be caused by external pressure or diseases such as diabetes mellitus (Japardi, 2002).

The table above shows the results of physiological reflexes, where the majority of people with diabetes still have good reflexes in the muscles in the upper limb, namely the right and left biceps brachii and the right and left Triceps brachii. Whereas physiological reflexes that are dominated by reflexes are lacking, which is the right and left quadriceps femoral and Achilles muscles. Motor damage in the form of no physiological reflexes was found on the quadriceps femoris and the right or left leg Achilles. Disturbances, in the form of decreased or loss of reflexes caused by damage to small fibers in the muscles due to injury agents (Sicco, 2009).

The results of motor damage assessment in this study found that the majority of respondents experienced a decrease in muscle strength in both legs. This is supported by researcher Rosyida (2016) that the majority of people with diabetes have decreased muscle strength in both legs. While other studies have found that motor damage in people with diabetes tends to be low because clients routinely go to community health centers (Syafi'i, 2018). people with diabetes who experience motor disturbances, as well as sensory and autonomic disorders, will cause diabetic ulcers.

People with diabetes who have diabetic ulcers have been clinically proven to have a history of peripheral nerve damage (Hampton, 2006).Peripheral nerves consisting of Schwan and myelin cells are susceptible to pressure injury, the cause of this vulnerability is still unknown with certainty (Japardi, 2002). However, diseases such as diabetes mellitus are suspected to be a risk factor for damage from the Schwan and myelin cells that line the peripheral nerves. Impaired motor nerve function is due to a lack of blood supply in the legs due to hyperglycemia (Syafi'i, 2018).

\section{CONCLUSION}

From the results of this study, the following conclusions can be concluded that demographic characteristics of people with diabetes are the majority in middle adulthood (71.6\%), female sex (53.9\%), with DM sufferings between 1-5 years $(58.3 \%)$, have GDS levels between $90-199 \mathrm{mg} / \mathrm{dL}(57.8 \%)$, have a history of smoking; history of comorbidities; and DFU $(67.6 \% ; 68.6 \% ; 9.2 \%)$. Forms of motor nerve damage that are examined include deformity, muscle strength, and physiological reflex function. The most common deformity found in the right or left foot is hallux valgus (38.2\%; $26.4 \%)$. Severe forms of damage to muscle strength were found on the right and left abduction (7.8\%), and right or left toe extension $(1.9 \% ; 2.9 \%)$. Motor damage in the form of no physiological reflexes found in the right and left Quadriceps femoral $(2 \% ; 1 \%)$, and right or left Achilles foot $(1 \%)$. The assessment of motor damage is dominated by a decrease in muscle strength both right and left $(75.4 \% ; 72.5 \%)$. Based on the results of the description of motor nerve damage to people with diabetes in the agricultural area, it is hoped that further action will take place in the form of real interventions from health services. The intervention is a preventive effort in order to prevent the worsening of motor nerve damage in people with diabetes. 


\section{REFERENCES}

Al-rubeaan, K., Derwish, M. Al, Ouizi, S., \& Youssef, A. M. (2015). Diabetic Foot Complications and Their Risk Factors from a Large Retrospective Cohort Study, 53(Cvd), 1-17. https://doi.org/10.1371/journal.pone.0124446

Arsono, S. (2005). Diabetes Mellitus Sebagai Faktor Risiko Kejadian Gagal Ginjal Terminal. Universitas Diponegoro Semarang.

Badan Penelitian Dan Pengembangan Kesehatan Kementerian Kesehatan. (2013). Riset Kesehatan DasaR 2013.

Bansal, D., Gudala, K., Muthyala, H., Esam, H. P., Nayakallu, R., \& Bhansali, A. (2014). Prevalence and risk factors of development of peripheral diabetic neuropathy in type 2 diabetes mellitus in a tertiary care setting. J Diabetes Investigation, 5(6), 714-721. https://doi.org/10.1111/jdi.12223

Betteng, R., Pangemanan, D., \& Mayulu, N. (2014). Analisis Faktor Resiko Penyebab Terjadinya Diabetes Melitus Tipe 2 Pada Wanita Usia Produktif Dipuskesmas Wawonasa. Jurnal e-Biomedik (eBM, Volume 2, 9.

Bus, S. A., Maas, Ma., Michels, R. P., \& Levi, M. (2009). Role of Intrinsic Muscle Atrophy in the Etiology of Claw Toe Deformity in Diabetic Neuropathy May Not Be as Straightforward as Widely Believed. Diabetes Care, 32(6). https://doi.org/10.2337/dc082174.

Dinas Kesehatan Kab. Jember. (2017). Laporan PTM 2017. Jember.

Hampton, S. (2006). Caring for the diabetic patient with a foot ulcer. British Journal of Nursing, 15(15).

Iroth, G. S. N., Kandou, G. D., \& Malonda, N. S. H. (2017). Hubungan Antara Umur Dan Pola Makan Dengan Kejadian Diabetes Melitus Tipe 2 Pada Pasien Rawat Jalan Di Wilayah Kerja Puskesmas Tenga Kecamatan Tenga. Media Kesehatan, 9(3).

Japardi, I. (2002). Peroneal Neuropathy. Dr ISKANDAR JAPARDI Fakultas Kedokteran Bagian Bedah Universitas Sumatera Utara. Sumatra Utara.

Jember, P. K. (PEMKAB). (2012). Potensi dan Produk Unggulan Jawa Timur. Jember.

Kartika, R. W. (2017). Pengelolaan gangren kaki Diabetik. Continuing Medical Education, 44(1), 18-22.

Kementerian Kesehatan RI. (2014). Pusat Data dan Informasi Kementerian Kesehatan RISituasi dan Analisis Diabetes. Pusat Data dan Informasi Kementerian Kesehatan RI. JAKARTA. https://doi.org/24427659

Nistiandani, A., Juniarto, A. Z., \& Dyan, N. S. (2018). Stages Of Grief Dan Depresi Pada Pasien Diabetes Mellitus. Universitas Diponegoro.

Saputri, E. G., Setiani, O., YD, N. A., \& Budiyono. (2018). Hubungan Riwayat Pajanan Pestisida Dengan Kejadian Diabetes Melitus Tipe 2 Pada Petani Penyemprot Di Kecamatan Ngablak Kabupaten Magelang. Jurnal Kesehatan Masyarakat (e-Journal), 6(1), 645-654.

Schie, C. H. Van, Vermigli, C., Carrington, A. L., \& Boulton, A. (2016). Muscle Weakness and Foot Deformities. Diabetes Care, 27(January), 7. https://doi.org/10.2337/diacare.27.7.1668

Syafi'i, M. R. (2018). Gambaran Klinis Neuropati Perifer Pada Penyandang Diabetes Melitus Di Wilayah Puskesmas Purwosari. Universitas Muhammadiyah Surakarta.

Tesfaye, S., Boulton, A. J. M., Dyck, P. J., Freeman, R., Horowits, M., Kempler, P., ... Valensi, P. (2010). Diabetic Neuropathies : Update on Definitions, Diagnostic Criteria , Estimation of Severity, and Treatments. care.diabetesjournals.org, 33(10), 2285-2293. https://doi.org/10.2337/dc10-1303

World Health Organization. (2016). Diabetes Country Profiles, 2016. 